\title{
Role of the Saw-Toothed Grain Beetle, Oryzaephilus Surinamensis (1.) in Date Palm Fruits Decay at Different Temperatures with Special References to its Thermal Requirements Estimation.
}

M.S. Fouad, A.H. Gharib and Asmaa, N. Mahmoud

Plant Protection Dept., Fac., Agric., Minia Univ., Minia, Egypt.

\begin{abstract}
Results showed that lab. Condition and $25^{\circ} \mathrm{C}$ were the of degrees of temperatures where decay and prevailing of the saw-toothed grain beetle occurred. The rearing of this insect on $40^{\circ} \mathrm{C}$ caused mortality of all adults and no adult emergence occurred, hence this degree of temperature prevented decay of dates. Also, the effect of four constant temperatures $\left(20,25,30\right.$ and $\left.35^{\circ} \mathrm{C}\right)$ on developmental rates of different stages of Oryzaephilus surinamensis (L.) was studied. The time required for development of different stages increased as the temperature decreased. The average thermal requirements needed for completing the development was 99.7, 559.8, 207.8 and 843.4 degree days for eggs, larvae, pupae and development period respectively.
\end{abstract}

\section{Introduction}

The saw-toothed grain beetle, Oryzaephilus surinamensis (L.) (Coleoptera: Silvanidae) is a major key pest of date fruits during the ripening and storage stages causing huge economical loss and qualitative damage of dates as shown by Shattir et al., (2002) and Moawed and Al- Ghamdi (2013) who reported that the infestation by $O$. surinamensis caused loss in quality and quantity of dry date varieties during storage. The temperature is considered as an important environmental factor that affects the rate of development of the insects, and controlled the success of the insect to live in a given temperature, it was particularly as practical point of view interesting for economic insects to obtain a useful and good forecast and predication system of insect population. Trematerra et al., (2016) and Yar et al., (2017). This work was pointed mainly to the following aspects such as recognizing the role of this pest in date fruits decay at different temperatures. Also, the effect of temperature on the duration of different stages and the thermal requirements of $O$.surinamensis were studied.

\section{Materials and Methods}

\section{1- Rearing technique:}

Adults of $O$. surinamensis were cultured in incubator at constant temperature $\left(25 \pm 2{ }^{\circ} \mathrm{C}\right)$ in the laboratory of Plant Protection Department, Faculty of Agriculture, Minia University. Stock culture was set up by using 50 pairs of $O$. surinamensis, which were kept in a plastic container $\left(8 \times 12 \mathrm{~cm}^{2}\right)$ contained $250 \mathrm{~g}$ of disinfested dates, and then tightly closed. The infested dates were isolated after three weeks and placed into another plastic container and this process was repeated till obtaining the pure $3^{\text {rd }}$ generation of saw-toothed grain beetle to start laboratory experiments.

2- Role of $O$. surinamensis in date palm fruits decay at different temperatures.

A number of 120 plastic jars of $12 \times 20 \mathrm{~cm}$ dimensions were tightly locked when used. In each jar, 10 healthy dates were put in half of the tubes, then
20 adults of the saw-toothed grain beetles were provided. The temperature degrees tested were lab. Temperature, 25 and $40^{\circ} \mathrm{C}$. Twenty jars were used for each degree of temperature. Ten tubes were randomly chosen for each degree of temperature to test decay after one, two, three and four months of storage. The infested dates were identified and calculated by observing the change in color, smell and shape of date so as to assign the rate of decay (Abdul Al-Husin, 1985). Also, the number of non-infested, decayed dates and the number of living and dead insects were calculated to determine the rate of mortality, the population density of the saw-toothed grain beetle and the rate of infestation (Al-Dosary, 2009).

\section{3- Estimation thermal requirements of $O$. surinamensis:}

All stages of $O$. surinamensis were kept under four constant temperatures in incubators $(20,25,30$ and $35^{\circ} \mathrm{C}$ ) to determine the incubation period, larval duration, pupal duration, and developmental period. However, the incubation period was recorded by obtaining one hundred eggs on four replicates of 30 gms lots of dates in $5 \times 10 \mathrm{~cm}$ plastic vials at each tested temperature and were observed until hatching. As for the larval development, 4 replicates of 25 newly hatched larvae were transferred, each into a separate glass tube $(7.5 \times 2.5 \mathrm{~cm}$.) (25 larvae/replicate). The larvae were reared on pieces of dates until adult emergence. Daily observation was made to count the pupated larvae and the adult emergence was recorded.

The rate of development for $O$. surinamensis stages (incubation period, larval duration, pupal duration and developmental period) were determined by the simple formula $\left(1 / \mathrm{t}^{*} 100\right)$ for the four constant temperatures.

The obtained data concerning the effectiveness of different constant temperature degrees on both immature and adult stages of $O$. surinamensis were subjected to statistical analysis where the theoretical development thresholds $\left(\mathrm{t}_{0}\right)$ and the accumulation thermal units $(\mathrm{k})$ were determined according to the formula of Abd- Elrazek (2009) and Dahi (2010). $\mathrm{K}=\mathrm{y}\left(\mathrm{T}-\mathrm{t}_{0}\right)$. 
Where: $y$ : developmental duration of a given stage, $\mathrm{T}$ : temperature in degree centigrade, $\mathrm{t}_{0}$ : lower threshold of development $\mathrm{K}$ : thermal units (degree days).

\section{Results and Discussion}

1- Role of $O$. surinamensis on date palm fruits decay at different temperatures:

Fruit decay presented in Table (1) revealed that the highest percentage weigh loss was recorded after four months of storing at $25^{\circ} \mathrm{C}(23.7 \%)$ and at lab. temperature $(16.8 \%)$.

Table 1. Effect of different degrees of temperatures and storing periods on date palm fruit decay by $O$. surinamensis.

\begin{tabular}{|c|c|c|c|c|c|c|c|c|c|c|c|c|}
\hline \multirow{2}{*}{$\begin{array}{l}\text { Storage } \\
\text { period } \\
\text { (month }\end{array}$} & \multicolumn{2}{|c|}{$\begin{array}{l}\text { Percentage } \\
\text { weight loss }\end{array}$} & \multirow{2}{*}{$\begin{array}{r}\text { of } \\
{ }^{\circ} \mathbf{C} \\
40\end{array}$} & \multicolumn{2}{|c|}{$\begin{array}{l}\text { No. of } \\
\text { emergence }\end{array}$} & \multirow{2}{*}{$\begin{array}{c}\text { adult } \\
{ }^{\circ} \mathrm{C} \\
\mathbf{4 0} \\
\end{array}$} & \multicolumn{2}{|c|}{$\begin{array}{l}\text { Percentage of } \\
\text { decay }\end{array}$} & \multirow{2}{*}{$\begin{array}{l}\text { date } \\
\mathbf{4 0} \\
{ }^{\circ} \mathbf{C} \\
\end{array}$} & \multicolumn{3}{|c|}{ Percentage of mortality } \\
\hline & Lab. & $\begin{array}{l}25 \\
{ }^{\circ} \mathrm{C}\end{array}$ & & Lab. & ${ }^{\circ} \mathrm{C} 25$ & & Lab. & $25^{\circ} \mathrm{C}$ & & Lab. & ${ }^{\circ} \mathrm{C} 25$ & $\begin{array}{l}\mathbf{4 0} \\
{ }^{\circ} \mathrm{C}\end{array}$ \\
\hline $\begin{array}{l}\text { One } \\
\text { month }\end{array}$ & 0.7 & 4.7 & - & 98 & 148 & - & 2.00 & 22.2 & - & 2.8 & 12.2 & 100 \\
\hline $\begin{array}{l}\text { Two } \\
\text { months }\end{array}$ & 3.00 & 10 & - & 241 & 485 & - & 16.4 & 53.6 & - & 16.4 & 19.7 & 100 \\
\hline $\begin{array}{l}\text { Three } \\
\text { months }\end{array}$ & 9.2 & 18.9 & - & 611 & 805 & - & 68.00 & 61.9 & - & 16.3 & 30.00 & 100 \\
\hline $\begin{array}{l}\text { Four } \\
\text { months }\end{array}$ & 16.8 & 23.7 & - & 861 & 954 & - & 93.00 & 100.0 & - & 25.6 & 38.8 & 100 \\
\hline L.S.D 0.05 & 3.74 & 3.11 & - & 8.95 & 9.1 & - & 19.95 & 15.83 & - & 7.24 & 5.14 & - \\
\hline
\end{tabular}

Also, the results in Table (1) showed significant differences among the degree of temperatures on the number of adult emergence of the saw- toothed grain beetle which grown on dates. The highest number of adults emerged was 954 at $25^{\circ} \mathrm{C}$ after four months of storing, while the lowest was (98) under lab. Conditions after one month of storing, but at $40^{\circ} \mathrm{C}$ no adult emergence was recorded. In addition, the highest percentage of infestation by $O$. surinamensis was $100 \%$ at $25^{\circ} \mathrm{C}$ after four months of storage, while the lowest percentage of infestation was $2 \%$ after one month under lab. conditions. Also, it was noticeable that as the period of storing increased the percentage of infested dates increased to 22.2, 53.6, 61.9 and $100 \%$ after one, two, three and four months of storing at $25^{\circ} \mathrm{C}$, respectively. In the same time, the percentage of date decay was null at $40^{\circ} \mathrm{C}$.

Concerning the percentage of adult mortality of $O$. surinamensis, (Table 1) showed significant differences between the degrees of temperature and the storing periods. Hundred percentages of mortality were recorded at $40^{\circ} \mathrm{C}$ after different periods of storing. Also, the highest percentage mortality at 25 ${ }^{\circ} \mathrm{C}$ was $38.7 \%$ after four months of storing, while the lowest percentage was $2.8 \%$ after one month of storing under the lab condition. Length of storing period increased the rate of decay because of the increase in the number of the insect individuals and in growth, as well as activity of the microorganisms that cause decay. Al-Dosary(2009) and Al-Deep(2012).

\section{2- Estimation of thermal requirements of $O$. surinamensis:}

\section{1. Egg stage:}

Data in Table (2) indicated that there were highly significant differences between the incubation periods recorded at $35^{\circ} \mathrm{C}$. and the values at $20^{\circ} \mathrm{C}, 25^{\circ} \mathrm{C}$ and $30^{\circ} \mathrm{C}$. The lower threshold of development $\left(\mathrm{t}_{0}\right)$ for the egg stage was $12.23^{\circ} \mathrm{C}$. The same Table showed that the average thermal units required for eggs development till hatching was 99.71 D. D's as determined by the thermal summation equation $\mathrm{k}=\mathrm{y}$ (T- 12.23).

\subsection{Larval stage:}

Concerning the effect of the four tested constant temperatures on the larval duration of $O$. surinamensis, it was noticed that the larval duration period decreased as the temperature increased, where the average durations were $35,26.3,21.5$ and 18 days at $20,25, \quad 30$ and $35^{\circ} \mathrm{C}$, respectively. The developmental zero for this stage was $3.9^{\circ} \mathrm{C}$. But, the average of thermal heat units for $O$. surinamensis larvae was $559.84 \mathrm{D}$. D's as estimated by the thermal summation equation $\mathrm{k}=\mathrm{y}$ (T-3.9). (Table3). A similar result was reported by Govindaraj et al., (2014).

\section{3. Pupal stage:}

Data in Table (4) show the effect of all tested temperatures on the pupal duration of $O$. surinamensis. The relationship obviously indicated that the time required for completion of pupal development decreased significantly as the temperature increased.

The lower threshold of pupal development was calculated (Table4) this value was found to be $6.6^{\circ} \mathrm{C}$. The average of thermal units in degree-days required for the completion of development of this stage was 207.8 D. D's. Govindaraj et al., (2014) 
Table 2. Development of $O$. surinamensis eggs under different constant temperatures and their thermal requirements

\begin{tabular}{lllll}
\hline Temp. $\left({ }^{\circ} \mathrm{C}\right)$ & Incubation period (Days) & Rate of development & $\mathrm{t}_{0}\left({ }^{\circ} \mathrm{C}\right)$ & Degree days \\
\hline $20^{\circ} \mathrm{C}$ & 11.75 & 8.5 & \multirow{2}{*}{12.23} & 99.71 \\
$25^{\circ} \mathrm{C}$ & 8.5 & 11.8 & & \\
$30^{\circ} \mathrm{C}$ & 5.75 & 17.2 & & \\
$35^{\circ} \mathrm{C}$ & 4.25 & 23.3 & & \\
$\mathrm{~F}_{\text {value }}$ & 96.14 & & & \\
$\mathrm{LSD}_{05 \%}$ & 1.02 & & & \\
$\mathrm{LSD}_{01 \%}$ & 1.43 & & & \\
\hline
\end{tabular}

Table 3. Development of $O$. surinamensis larvae under different constant temperatures and their thermal requirements.

\begin{tabular}{lllll}
\hline Temp. $\left({ }^{\circ} \mathrm{C}\right)$ & Larval duration (Days) & Rate of development & $\mathrm{t}_{0}\left({ }^{\circ} \mathrm{C}\right)$ & Degree days \\
\hline $20^{\circ} \mathrm{C}$ & 35.0 & 2.9 & 3.9 & 559.84 \\
$25^{\circ} \mathrm{C}$ & 26.3 & 3.8 & & \\
$30^{\circ} \mathrm{C}$ & 21.5 & 4.7 & & \\
$35^{\circ} \mathrm{C}$ & 18.0 & 5.6 & & \\
$\mathrm{~F}_{\text {value }}$ & 189.29 & & & \\
$\mathrm{LSD}_{05 \%}$ & 1.65 & & & \\
$\mathrm{LSD}_{01 \%}$ & 2.31 & & \\
\hline
\end{tabular}

Table 4. Development $O$. surinamensis pupae under different constant temperatures and its thermal requirements.

\begin{tabular}{lllll}
\hline Temp. $\left({ }^{\circ} \mathrm{C}\right)$ & Pupal duration (Days) & Rate of development & $\mathrm{t}_{0}\left({ }^{\circ} \mathrm{C}\right)$ & Degree days \\
\hline $20^{\circ} \mathrm{C}$ & 15.5 & 6.5 & 6.6 & 207.8 \\
$25^{\circ} \mathrm{C}$ & 11.3 & 8.9 & & \\
$30^{\circ} \mathrm{C}$ & 9.0 & 11.1 & & \\
$35^{\circ} \mathrm{C}$ & 7.3 & 13.8 & & \\
$\mathrm{~F}$ value & 71.76 & & & \\
$\mathrm{LSD}_{0.05}$ & 1.30 & & & \\
LSD $_{0.01}$ & 1.82 & & & \\
\hline
\end{tabular}

\subsection{The generation:}

Data in Table (5) indicate that the highest mean duration of generation for $O$. surinamensis was 62.5 days and lowest was 29.5 days at 20 and $35^{\circ} \mathrm{C}$,respectively. Data revealed that increasing temperature accelerated the developmental rate of $O$. surinamensis, where it reached the maximum velocity at $35^{\circ} \mathrm{C}$. Statistical analysis indicated that there were significant relationships among all values of mean generation periods at all tested temperatures. Kilpatrick et al. (2004) found that the development from egg to adult for the same pest took approximately 2 months.

The lower threshold of generation development (Table 5) was found to be $6.5^{\circ} \mathrm{C}$. The average of thermal units in degree-days required for the completion of all developmental stages was $843.4 \mathrm{D}$. D's. Lukas (2008).

Table 5. Duration of $O$. surinamensis generation under different constant temperatures and its thermal requirements.

\begin{tabular}{llllc}
\hline Temp. $\left({ }^{\circ} \mathrm{C}\right)$ & Duration of generation (Days) & Rate of development & $\mathrm{t}_{0}\left({ }^{\circ} \mathrm{C}\right)$ & Degree days \\
\hline $20^{\circ} \mathrm{C}$ & 62.5 & 1.6 & & \\
$25^{\circ} \mathrm{C}$ & 45.0 & 2.2 & 6.52 & 843.4 \\
$30^{\circ} \mathrm{C}$ & 36.6 & 2.7 & & \\
$35^{\circ} \mathrm{C}$ & 29.5 & 3.4 & & \\
$\mathrm{~F}$ value & 469.95 & & & \\
$\mathrm{LSD}_{05 \%}$ & 2.01 & & & \\
$\mathrm{LSD}_{01 \%}$ & 2.82 & & & \\
\hline
\end{tabular}

\section{References}

Abd-Elrazek, A. A. N. (2009): Ecological studies on certain insect of rice crop and its control in Northern Delta, Egypt. Ph. D. thesis, Fac. Agric. Al-Azhar Univ.
Abdul Al-Husin, A. (1985): Date palm, dates and them pest. Basrah Uni. Press.576p.

Al-Deeb, (2012): Lethal time at different temperatures and date variety preference of the saw-toothed grain beetle in stored dates. Agric. Sci.,3(6):789-794. 
Al-Dosary, N. H. (2009): Role of the saw-toothed grain beetle Oryzaephilus surinamensis, L. Coleoptra: Silvanidae in date palm fruits decay at different temperatures. Basrah J. for Date Palm Researches., 8(2):1-14.

Dahi, F. H. (2010): Lower threshold of development and accumulated heat units requirements for different stages of the American bollworm Helicoverpa armigera hup. Bull. Ent. Soc. Egypt. (87) 225-238.

Govindaraj, R.; Mohankumar, S.; Rajasekaran, B. and Mohan, S. (2014): Biology of the sawtoothed grain beetle, Oryzaephilus surinamensis (Linnaeus) on different stored products and its host associated genetic variability. $11^{\text {th }}$ international working conference on stored product protection. Chiang Mai, Thailand. 128135.

Kilptrck, A.L., Zungoli, P.A. and Benson, E.P. (2004): Saw-toothed grain beetle. Cooperative Extension Service. Dept. Entomol. Clemson Univ., Clemson.

Lukáš, J. (2008). Use of Cephalonomia tarsalis for the biological control of Oryzaephilus surinamensis. Prague Res. Instit., Prague (in Czech)
Moawad, S. S. and Al-Ghamdi, F. F. (2013): Susceptibility of Some Dry Date Cultivars to Infestation by Oryzaephilus surinamensis (L.) (Coleoptera: Silvanidae). American J. Experimen. Agric., 3(3): 651-663.

Shattir, E.A.; Abu Goukh, A.A. and Karam Alla, C. M. (2002): Physical and chemical characteristics and yield components of Barakawi and Gondaila dry dates. Sudan Journal of Scientific Research. National Centre for Research, 8: 119-131.

Trematerra, P.; Nickolas, G. K. and Christos, G. A. (2016): Laboratory tests on the ability of Oryzaephilus surinamensis adults to locate different types of chocolate varying in quantity of cocoa. Bulletin of Insectol. 69 (1): 21-24.

Yar, M. A.; Hassan, M. W.; Ahmad, M.; Ali, F. and Jamil, M. (2017): Effect of Packaging Materials and Time Period for Damage in Packaging and Weight Loss in Packed Wheat Flour (Triticum aestivum L.) by Red Flour Beetles Tribolium castaneum Herbst (Coleoptera: Tenebrionidae). J. Agric. Sci., 9 (4): 242- 247.

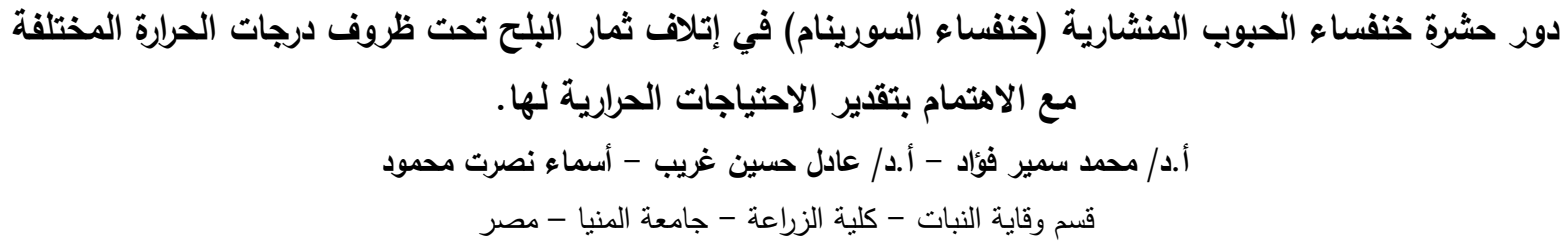

